\title{
Review \\ Virulence Factors of Enteric Pathogenic Escherichia coli: A Review
}

\author{
Babak Pakbin 1,2,3 ${ }^{\mathbb{D}}$, Wolfram M. Brück ${ }^{1, * \mathbb{D}}$ and John W. A. Rossen ${ }^{2} \mathbb{D}$ \\ 1 Institute for Life Technologies, University of Applied Sciences Western Switzerland Valais-Wallis, \\ 1950 Sion 2, Switzerland; b.pakbin@ut.ac.ir \\ 2 Department of Medical Microbiology and Infection Prevention, University Medical Center Groningen, \\ University of Groningen, 9713 GZ Groningen, The Netherlands; john.rossen@gmail.com \\ 3 Medical Microbiology Research Center, Qazvin University of Medical Sciences, Qazvin 15315-3419, Iran \\ * Correspondence: wolfram.bruck@hevs.ch
}

Citation: Pakbin, B.; Brück, W.M.;

Rossen, J.W.A. Virulence Factors of Enteric Pathogenic Escherichia coli: A Review. Int. J. Mol. Sci. 2021, 22, 9922. https://doi.org/10.3390/ ijms22189922

Academic Editor: Tanneke Den Blaauwen

Received: 15 August 2021

Accepted: 12 September 2021

Published: 14 September 2021

Publisher's Note: MDPI stays neutral with regard to jurisdictional claims in published maps and institutional affiliations.

Copyright: (c) 2021 by the authors. Licensee MDPI, Basel, Switzerland. This article is an open access article distributed under the terms and conditions of the Creative Commons Attribution (CC BY) license (https:// creativecommons.org/licenses/by/ $4.0 /)$.

\begin{abstract}
Escherichia coli are remarkably versatile microorganisms and important members of the normal intestinal microbiota of humans and animals. This harmless commensal organism can acquire a mixture of comprehensive mobile genetic elements that contain genes encoding virulence factors, becoming an emerging human pathogen capable of causing a broad spectrum of intestinal and extraintestinal diseases. Nine definite enteric E. coli pathotypes have been well characterized, causing diseases ranging from various gastrointestinal disorders to urinary tract infections. These pathotypes employ many virulence factors and effectors subverting the functions of host cells to mediate their virulence and pathogenesis. This review summarizes new developments in our understanding of diverse virulence factors associated with encoding genes used by different pathotypes of enteric pathogenic E. coli to cause intestinal and extraintestinal diseases in humans.
\end{abstract}

Keywords: enteric pathogenic Escherichia coli; E. coli pathotypes; virulence factor genes

\section{Introduction}

Escherichia coli, rod-shaped and gram-negative bacteria belonging to the Enterobacteriaceae family, were first isolated from infant stool and characterized by Theodor Escherich in 1885 [1]. A few hours after birth, E. coli colonize and inhabit the gastrointestinal tract of infants. Regarding several mutual benefits, humans and commensal E. coli strains coexist without any adverse effects. However, commensal $E$. coli may cause disease in patients with breached gastrointestinal barriers or immunocompromised hosts [2]. Notably, certain $E$. coli mediate various diseases, including intestinal and extraintestinal disorders in humans and animals worldwide. Nine pathovars have been described for E. coli strains isolated from humans causing diarrheagenic and extraintestinal diseases [3]. Of these, seven pathotypes have been described as enteric pathogenic E. coli, including Enteropathogenic E. coli (EPEC), Enterohaemorrhagic E. coli (EHEC), Enterotoxigenic E. coli (ETEC), Enteroinvasive E. coli (EIEC), Enteroaggregative E. coli (EAEC), Diffusely adherent E. coli (DAEC), and, a new pathotype, Adherent-Invasive E. coli (AIEC), causing mostly diarrhea and intestinal disorders. However, the EHEC pathotype has been implicated in extraintestinal diseases such as Hemolytic Uremic Syndrome (HUS) [4]. Many of these pathotypes constitute public health concerns as foodborne pathogens and caused several fatal outbreaks in developing and developed countries [5,6]. Enteric E. coli pathotypes are implicated in many diseases through distinctly different pathogenesis. Pathogenesis is the process by which pathogens cause disease or disorder, often by expressing virulence-factor-encoding genes $[7,8]$.

Virulence factors are specific molecules, primarily proteins produced and released by bacteria, fungi, protozoa, and viruses. These factors are encoded by specific genes located on the chromosome or mobile genetic elements (e.g., plasmids or transposons) in bacterial pathogens $[9,10]$. Each E. coli pathotype has its characteristic pathogenicity mechanisms and 
a specific profile of virulence factors encoded by specific gene clusters. Genes associated with pathogenicity may encode activities such as adhesion, invasion, attachment, iron acquisition, motility, and toxin activity, among others. We can distinguish four main virulence classes of E. coli pathotypes: colonization, fitness, toxins, and effectors; each consists of several specific virulence factors with a definite function and activity (Table 1). It is noteworthy that different enteric and extraintestinal pathotypes of $E$. coli isolates share the same virulence factors and strategies [11]. Many virulence factors associated with enteric E. coli pathotypes implicated in intestinal and extraintestinal disorders have been identified in the last years [12]. The investigation of these virulence factors and the associated encoding genes can provide explicit knowledge about the interaction between these factors in enteric E. coli pathotypes and host proteins at the molecular level, indicating how they lead to diseases and can implement preventive strategies against them [13]. This review summarizes recent advances in our understanding of virulence factors and the associated genes in enteric pathogenic E. coli.

Table 1. Virulence factor genes of enteric E. coli pathotypes: Colonization, fitness, toxins, and effectors.

\begin{tabular}{|c|c|c|c|}
\hline Class & Virulence Factor & Activity/Function & Pathotype \\
\hline Colonization & $\begin{array}{l}\text { bfp } \\
\text { eae } \\
\text { tir } \\
\text { lifA } \\
\text { csgA } \\
\text { fimA } \\
\text { fimH } \\
\text { bcsA } \\
\text { eha } \\
\text { saa } \\
\text { sab } \\
\text { toxB } \\
\text { nleB } \\
\text { nleE } \\
\text { nleH } \\
\text { bleG } \\
\text { lfp } \\
\text { CFA/I } \\
\text { CFA/II } \\
\text { CFA/IV } \\
\text { CS1-6 } \\
\text { etpA } \\
\text { aggR } \\
\text { aggA } \\
\text { aafA } \\
\text { agg3A } \\
\text { agg4A } \\
\text { agg5A } \\
\text { aap } \\
\text { afaA-E } \\
\text { DraA-E } \\
\text { daaA-E } \\
\text { pop }\end{array}$ & $\begin{array}{l}\text { adherence, } \\
\text { attaching and effacing of enterocyte, } \\
\text { translocated intimin receptor, } \\
\text { initial attachment to the enterocytes, } \\
\text { curli fimbriae, } \\
\text { type I fimbriae, } \\
\text { type I fimbriae, } \\
\text { cellulose structure, } \\
\text { biofilm formation, } \\
\text { biofilm formation, } \\
\text { biofilm formation, } \\
\text { biofilm and adhesion establishment, } \\
\text { biofilm formation, } \\
\text { biofilm formation, } \\
\text { biofilm formation, } \\
\text { biofilm formation, } \\
\text { long polar fimbriae, initial attachment, } \\
\text { colonization factor, } \\
\text { colonization factor, } \\
\text { colonization factor, } \\
\text { colonization (coli surface antigen), } \\
\text { initial attachment, } \\
\text { attachment and adherence, } \\
\text { aggregative adhesion fimbria, } \\
\text { aggregative adhesion fimbria, } \\
\text { aggregative adhesion fimbria, } \\
\text { aggregative adhesion fimbria, } \\
\text { aggregative adhesion fimbria, } \\
\text { dispersin, dispersion of EAEC, } \\
\text { Afa/Dr adhesins, IL-8 secretion, } \\
\text { cytoskeleton rearrangement, destroying microvilli, } \\
\text { Afa/Dr adhesins, IL-8 secretion, expression of MICA } \\
\text { cytoskeleton rearrangement, destroying microvilli, } \\
\text { Afa/Dr adhesins, IL-8 secretion, expression of MICA } \\
\text { type I pili, adhesin, }\end{array}$ & $\begin{array}{l}\text { EPEC } \\
\text { EPEC, EHEC } \\
\text { EPEC, EHEC } \\
\text { EPEC } \\
\text { EPEC, EHEC } \\
\text { EPEC, EHEC, DAEC } \\
\text { ETEC, AIEC } \\
\text { EPEC } \\
\text { EHEC } \\
\text { EHEC } \\
\text { EHEC } \\
\text { EHEC } \\
\text { EHEC } \\
\text { EHEC } \\
\text { EHEC } \\
\text { EHEC } \\
\text { EHEC } \\
\text { ETEC } \\
\text { ETEC } \\
\text { ETEC } \\
\text { ETEC } \\
\text { ETEC } \\
\text { EAEC } \\
\text { EAEC } \\
\text { EAEC } \\
\text { EAEC } \\
\text { EAEC } \\
\text { EAEC } \\
\text { EAEC } \\
\text { DAEC }\end{array}$ \\
\hline
\end{tabular}


Table 1. Cont

\begin{tabular}{|c|c|c|c|}
\hline Class & Virulence Factor & Activity/Function & Pathotype \\
\hline \multirow[t]{6}{*}{ Fitness } & sdiA & quorum sensing signaling, & EPEC \\
\hline & iutA & aerobactin synthesis, & EIEC \\
\hline & iucB & complex siderophore iron receptor, & EIEC \\
\hline & yjaA & polypeptide stress response protein, & AIEC \\
\hline & fyuA & ferric yersiniabactin uptake, & AIEC \\
\hline & kpsMT II & capsule synthesis, & AIEC \\
\hline \multirow[t]{16}{*}{ Toxins } & stx1 & $\begin{array}{l}\text { shiga toxin, surface localization of nucleolin and } \\
\text { cytotoxic effect, }\end{array}$ & EHEC \\
\hline & stx2 & $\begin{array}{l}\text { shiga toxin, surface localization of nucleolin and } \\
\text { cytotoxic effect, }\end{array}$ & EHEC \\
\hline & estA & $\begin{array}{l}\text { ST I toxin, watery and secretory diarrhea, secretion of } \\
\text { chemokines and cytokines, }\end{array}$ & ETEC \\
\hline & estB & $\begin{array}{l}\text { ST II toxin, watery and secretory diarrhea, secretion of } \\
\text { chemokines and cytokines, }\end{array}$ & ETEC \\
\hline & LT I & watery diarrhea, & ETEC \\
\hline & LT II & watery diarrhea, & ETEC \\
\hline & eatA & SPATE, & ETEC, EIEC \\
\hline & astA & enteroaggregative heat-stable toxin, secretory diarrhea, & ETEC, EAEC, DAEC \\
\hline & ShET1 & shigella enterotoxin 1 , secretary intestinal activity, & ETEC \\
\hline & ShET2 & shigella enterotoxin 2, secretary intestinal activity, & ETEC \\
\hline & pet & $\begin{array}{l}\text { SPATE, plasmid encoded toxin, inducing epithelial cell } \\
\text { extrusion, host cell entering, }\end{array}$ & EAEC, DAEC \\
\hline & pic & $\begin{array}{l}\text { SPATE, ShET1 expression, inducing epithelial cell } \\
\text { extrusion, mucolytic activity, }\end{array}$ & EIEC, EAEC \\
\hline & $\operatorname{sig} \mathrm{A}$ & SPATE, cytotoxin, accumulation of intestinal fluid, & EIEC, EAEC, DAEC \\
\hline & sat & $\begin{array}{l}\text { SPATE, secreted autotransporter toxin, impairing tight } \\
\text { junction, mediating autophagy, }\end{array}$ & EAEC, DAEC \\
\hline & sepA & $\begin{array}{l}\text { shigella extracellular enterotoxin, cytotoxin, IgA } \\
\text { protease like homologue, }\end{array}$ & EAEC \\
\hline & hlyE & alpha hemolysin toxin, & EAEC \\
\hline \multirow[t]{19}{*}{ Effectors } & espA & translocator structures of T3SS, E. coli common pili, & EPEC, ETEC \\
\hline & espB & translocator structures of T3SS, phagocytosis inhibition, & EPEC \\
\hline & espC & cleavage of T3SS translocator structures, & EPEC \\
\hline & espD & translocator structures of T3SS, & EPEC \\
\hline & espF & $\begin{array}{l}\text { mitochondrial death, tight junction disruption, immune } \\
\text { evasion, host cell death, }\end{array}$ & EPEC, EHEC \\
\hline & espH & phagocytosis inhibition, & EPEC \\
\hline & espJ & phagocytosis inhibition, biofilm formation, & EPEC, EHEC \\
\hline & espP & cleavage of T3SS translocator structures, & EPEC, DAEC \\
\hline & espT & host cell death, & EHEC \\
\hline & MAP & $\begin{array}{l}\text { disrupt mitochondrial membrane functionality, host cell } \\
\text { death, }\end{array}$ & EPEC \\
\hline & nleA & $\begin{array}{l}\text { inflammasome activation, tight junction disruption, } \\
\text { cytokines secretion inhibition, }\end{array}$ & EPEC \\
\hline & etp & Autotransporter protein, & ETEC \\
\hline & tolC & secretion of ST toxins, & ETEC \\
\hline & nleF & host cell death, inflammasome activation, & EPEC, EHEC \\
\hline & cif & cell cycle disruption, delays apoptosis, & EPEC \\
\hline & ipaA & $\begin{array}{l}\text { Type III effector, cytoskeleton reorganization, cell death } \\
\text { blockage, }\end{array}$ & EIEC \\
\hline & ipaB & $\begin{array}{l}\text { Type III effector, adhesion, phagosome escape, cell } \\
\text { turnover, }\end{array}$ & EIEC \\
\hline & ipaC & $\begin{array}{l}\text { Type III effector, adhesion, actin polymerization, } \\
\text { phagosome escape, }\end{array}$ & EIEC \\
\hline & ipaD & $\begin{array}{l}\text { Type III effector, adhesion, phagosome escape, cell death } \\
\text { blockage, }\end{array}$ & EIEC \\
\hline
\end{tabular}


Table 1. Cont.

\begin{tabular}{llll}
\hline Class & Virulence Factor & Activity/Function & Pathotype \\
\hline ipaH & $\begin{array}{l}\text { dampen the inflammatory responses, invasion, } \\
\text { inhibition of host cell trafficking membrane, inhibition } \\
\text { of inflammasomes, }\end{array}$ & $\begin{array}{l}\text { EIEC, AIEC } \\
\text { EIEC }\end{array}$ & EIEC \\
ipaJ & cytoskeleton reorganization, ruffle formation, & EIEC \\
cytoskeleton reorganization, & EIEC \\
ipgD & cytoskeleton reorganization, cell death blockage, & EIEC \\
virA & autophagy inhibition, & EIEC \\
virB & virulence factor gene synthesis, & EIEC \\
virF & virulence factor gene expression, & EIEC \\
virG & Actin nucleation, & EIEC \\
ospB & dampen the inflammatory responses, & EIEC \\
ospE & cell detachment, & EIEC \\
ospF & dampen the inflammatory responses, & EIEC \\
ospI & dampen the inflammatory responses, & EIEC \\
ospZ & dampen the inflammatory responses, & ETEC \\
icsB & dampen the inflammatory responses, & EAEC \\
aaiA-Y & autophagy inhibition, & AIEC \\
\hline
\end{tabular}

\section{Enteropathogenic Escherichia coli (EPEC)}

EPEC is the principal cause of diarrheal diseases and outbreaks in infants characterized for the first time in the UK in 1945, with a high morbidity and mortality rate in children under six months of age. The EPEC rate in developed countries has decreased in recent decades. However, it is one of the major public health concerns for infants and adults in developing countries [14]. Some pathogenesis mechanisms of EPEC, such as the attaching and effacing (A/E) virulence factors, are shared with pathogens such as rabbit-EPEC, Citrobacter rodentium in mice, EHEC, and Escherichia albertii [15]. Foodstuffs, particularly milk and ground beef, are a vehicle of EPEC transmission to humans and animals and lead to intestinal infections [16-18].

Histopathologically, EPEC belong to the A/E pathogens. The main virulence-factorencoded genes of EPEC are located on a $35.62 \mathrm{~kb}$ chromosomal pathogenicity island (PAI) within 41 open reading frames (ORFs) and a pathogenic plasmid-termed locus of enterocyte effacement (LEE) and EPEC adherence factor (EAF), respectively [19]. LEE gene expression is modulated by the LEE-encoded regulator gene, located on the first part of the LEE. Another PAI of EPEC is termed the EspC island, encoding a serine protease autotransporter enterotoxin gene with the same name, and this is the only toxin released by EPEC, which can lead to epithelial cell necrosis [14]. Regarding the EAF plasmid presence/absence, EPEC is classified into typical (t-EPEC) with complete virulence genes and atypical EPEC without EAF-harboring operon for bundle type IV pili ( $b f p)$ [20]. The most prominent virulence factors of EPEC in both typical and atypical pathogens are located on the LEE. This PAI is a type-three secretion system (T3SS) comprising the EspA, EspB, and EspD (EPEC secreted protein) translocator proteins, effector proteins (Map, EspF, EspG, EspH, $E s p Z$ ), the proteins involved in intimate adherence, and regulatory elements [21]. Gut microbiome surface molecules, oxygen levels, and hormones in the environment mediate the signaling of LEE-activating transcription. A/E is initiated with the reaction between the outer membrane intimin and the translocated intimin receptor encoded by eae and tir genes, respectively [22]. Before T3SS expression following a stable attachment by intiminTir interaction and effectors injection, EPEC sticks to the surface of the host cells (initial attachment) using pili-like structures [23]. Type-IV pili (bfp) in a-EPEC and the lymphocyte inhibitory factor (lifA/efa1) in t-EPEC mediate the initial attachment to the enterocytes located in the small bowel considering the first step of A/E following the formation of localized microcolonies. T3SS is a complex injectisome machine in molecular nano- 
scale including more than 20 main proteins and consisting of three principal extracellular appendages: the needle, filament, and translocation pore; structurally, it is composed of a syringe with a central channel embedded into the bacterial membrane by ring structures and a supramolecular structure on the top of the needle connected to the host cell [24]. $E s p A, e s p B$, and $\operatorname{esp} D$ proteins construct different translocator structures of T3SS, and these proteins are cleaved by esp $P$ and $e s p C$ [25]. After the translocation of Tir, a strong attachment is formed while the translocated protein interacts with intimin. The first result of the Tir-intimin interaction is the induction of a cytoskeletal rearrangement and the pedestal formation underneath the pathogen attachment side in the host cell [26]. The translocated Tir protein is phosphorylated by tyrosine kinase in the host cell. The phosphorylation of Tir recruits the NcK protein leading to the activation of the neural Wiskott-Aldrich syndrome protein (N-WASP), the stimulation of the actin-related protein (ARP) 2/3, and the mediation of actin polymerization and rearrangement, which results in pedestal formation. This cytoskeletal rearrangement contributes to immune modulation and diarrhea. A thick biofilm formation also has a crucial role in EPEC pathogenesis [27]. The activation of biofilm formation is mediated by Quorum-sensing encoded by the suppressor of the division inhibitor (SdiA) gene. However, for biofilm formation, bacteria demand structures to support these characteristic curli fimbriae, type-I fimbriae, and the cellulose encoded in EPEC by csgA, fimA, and bcsA genes, respectively [28].

The next step in EPEC pathogenesis is the translocation of LEE and Nle effectors and proteins into the host cell through the T3SS. Some of these effectors efface the host cell with multiple functionalities. In addition to attachment and actin pedestal formation, Tir inhibits the NF-kB signaling as the immune evasion mechanism in EPEC pathogenesis [29]. The mitochondrial-associated protein (MAP) shares the Trp-xxx-Glu motif conferring GTPase GEF activity. GEF induces the Cdc42 factor and contributes to filopodia formation at the bacterial attachment site. MAP also disrupts the mitochondrial membrane functionality, contributing to the host cell's death. Another prominent effector is NleA (espI), having many roles, as proceeding with the NLRP3 inflammasome activation, tight junction disruption, and inhibition of the secretion of host cell cytokines [30]. EspF is a multi-function effector inducing mitochondrial death, disrupting the tight junction integrity, and implicated in phagocytosis inhibition, contributing to the immune evasion of EPEC during the pathogenesis. EspB, $H$, and $J$ genes also expressed proteins to inhibit phagocytosis [31]. Another multi-functional non-LEE effector is nleF, which activates the inflammasome by binding to caspase-4, dampening the cellular immune response. EspF, espT, MAP, nleF, and the cycle-inhibiting factor (Cif) induce host cell death by blocking the progression of the cell cycle. Despite the identification of the functions of these effectors, multi and single effects of many Nle and esp proteins secreted by EPEC and other A/E pathogens have not been characterized yet (Table 1) [32].

\section{Enterohaemorrhagic Escherichia coli (EHEC)}

EHEC cause diarrhea, hemorrhagic colitis (HC) with bloody diarrhea, and hemolytic uremic syndrome (HUS) in humans and are implicated in several foodborne outbreaks in developed countries. The main reservoir of this pathogen is the intestinal tract of cattle. EHEC was first isolated from a patient with bloody diarrhea and gastrointestinal disorder in 1982 and led to a worldwide pandemic [33]. EHEC as foodborne A/E pathogens are mainly transmitted to humans through contaminated food and water [34]. Outbreaks of EHEC serotypes usually have occurred via the fecal-oral route by person-to-person transmission, animal contact, and consumption of under-thermally processed foods as well as undercooked meat products, unpasteurized apple juice, raw milk, or cross-contaminated raw vegetables such as lettuce and bean sprouts. Raw flour has also been recently identified as a source of EHEC outbreaks [8,35-37].

The most important serotype playing a role in EHEC outbreaks is O157: H7, which is still considered a serious health concern in Japan, Europe, and North America. EHEC serotype O104: H4 was first isolated from a gastrointestinal infection and HUS outbreak 
by the consumption of sprouts in Germany in 2011. From there, it was spread out around the world. However, the genome sequencing of this serotype revealed that it belongs to both EHEC and enteroaggregative E. coli (EAEC) pathotypes, introducing a new emerged pathotype of E. coli termed enteroaggregative hemorrhagic E. coli (EAHEC) [34,38,39].

The shiga-like toxin (SLT), also termed verotoxin and encoded by stx genes, is the main virulence factor in EHEC serotypes which belongs to the shiga-toxin producing E. coli group and is responsible for pathological manifestations leading to specific disease symptoms caused during EHEC infections, such as HUS and renal failure $[8,40]$. SLT includes two subgroups, st $x 1$ and st $x 2$, and different subtypes. St $x 2 a$, st $x 2 c$, and st $x 2 d$ positive EHEC isolates are strongly associated with HC and HUS compared to other stx-subgroups and subtypes $[41,42]$. The shiga toxin is an $\mathrm{AB}_{5}$ toxin. Subunit $\mathrm{A}$ is cleaved into two fragments, $A_{1}$ and $A_{2}$, by reducing a disulfide bond, releasing the $A_{1}$ fragment into the cytoplasm. It exerts the cytotoxic effect by enzymatically deadenylating position 4324 of $28 \mathrm{~s}$ rRNA of the 60 s ribosome, leading to the inhibition of protein synthesis and cell death [43]. In addition, to triggering ribotoxic stress, the $\mathrm{A}_{1}$ fragment of stx induces cytokine production and activates the apoptotic cell pathways. Protein translation inhibition and immune response modulation are mainly responsible for the pathogenesis of shiga toxin's subunit A. The A subunit fragments need non-covalent binding with homopentameric B subunits to enter the target cell and induce the cytotoxic effect. B subunits of shiga toxins specifically bind to the carbohydrate moiety of glycosphingolipid globotriaosylceramide ( $\mathrm{Gb}_{3}$ or $\left.\mathrm{CD} 77\right)$, a specific receptor molecule found on the surface of kidney epithelial and intestinal Paneth cells in humans. After receptor binding and $\mathrm{Gb}_{3}$-stx complex formation, the attached toxins form a cluster, membrane invagination, and endocytic pit formation at the plasma membrane of the cell [44]. These invaginations separate from the plasma membrane to form intracellular toxin carriers. Intracellular trafficking of the endocytic carriers is performed by moving from the early endosome to the Golgi and the endoplasmic reticulum before stx escapes from the $\mathrm{Gb}_{3}$-stx complex to exert the cytotoxic effect. Stx toxins are transported to the non-target $\left(\mathrm{Gb}_{3}\right.$-negative) cells by neutrophil transmigration, micropinocytosis, and $\mathrm{Gb}_{3}$-independent transcytosis. Inside $\mathrm{Gb}_{3}$-negative cells, stx toxins only induce an inflammatory response and do not prevent protein synthesis [45]. There is a lack of a definite secretion system to release st $x$ toxins by EHEC serotypes. Shiga toxins are released through phage-mediated lysis while specific triggers, including SOS-inducing agents such as antibiotic therapy or DNA damages, depress the transcription of lytic phase genes. This contributes to the lysis of the STEC bacterial cell and the release of shiga toxins into the extracellular milieu [46].

EHEC serotypes are a subgroup of STEC strains containing adhesin and attachment virulence factors encoded by the LEE pathogenicity island. Adhesin proteins are involved in the colonization and biofilm formation of EHEC on the abiotic and biological surfaces [47]. The first step of EHEC adherence to intestinal epithelial cells is initial attachment. Recent studies showed that the initial contact and attachment between the pathogen and the host cell are mediated through the interaction between the pathogen's long polar fimbriae (lfp gene) and extracellular membrane proteins in the host cell, including fibronectin, collagen IV, and laminin [48]. They closely intimate the attachment, and the A/E effect occurs via the interactions of intimin (encoded by eae gene) and the receptor proteins in the host cell membrane, consisting of Tir (injected through T3SS), nuclein, and $\beta 1$-integrins. The A/E pathogenic mechanism in EHEC is different from that in EPEC. Pedestal formation and actin rearrangement are mediated through an Nck-independent mechanism. Cell actin cytoskeleton rearrangement is induced while the Tir-intimin complex links to the EspF protein by a homologue protein of insulin receptor substrate [49]. N-WASP and ARP2/3 are activated for actin assembly via interaction with the induced EspF. Curli (encoded by csg genes) are recognized as adherence and colonization factors. Colonization, microcolonies, and biofilm formation are mediated by E. coli common pilus (ECP) and Hemorrhagic E. coli common pilus (HCP) via interaction with the surface of the host cell [49]. Some proteins, such as type $1, \mathrm{~F} 9$, and E. coli laminin-binding fimbriae are involved in the 
adhesion to the host cell. Autotransporters including Eha, Saa, and Sab proteins released by EHEC contribute to biofilm formation and adhesion [50]. Moreover, a plasmidal gene termed ToxB, located on the $\mathrm{pO} 157$ plasmid, may be involved in the adhesion in serotype O157: H7 and other EHEC strains. It is worthwhile to note that specific environmental conditions such as $\mathrm{pH}$, temperature, and nutrient limitations induce the transcription and expression of adhesin genes through some signaling systems, such as the secretion of quorum-sensing molecules [51]. EHEC serotypes secrete twice as many effectors into the host cell via T3SS than EPEC. Host inflammatory responses induced by A/E, colonization, and biofilm formation also contribute to the symptoms of GI disorders. NleF, as a non-LEE effector, is considered a prominent virulence factor because of the counteraction to the host inflammatory response and inhibition of cell death. Several non-LEE-effectors such as NleB, NleE, BleG, NleH, and EspJ have been recently shown to mediate EHEC survival and biofilm formation (Table 1) [52-54].

\section{Enterotoxigenic Escherichia coli (ETEC)}

The E. coli pathotype ETEC releasing enterotoxins in the human small intestine is the principal cause of travelers' and children diarrhea in developing countries. The highest infection and mortality rates of ETEC are found in children under the age of two. According to the World Health Organization's reports, ETEC annually causes more than 157,000 human diarrheal cases that lead to death [55]. The main symptoms caused by ETEC infection are mild to severe diarrhea and abdominal pain. Other symptoms, such as vomiting, nausea, fever, and headache have rarely been observed [56]. ETEC are also animal pathogens causing acute diarrheal diseases in cattle, poultry, and piglets [57]. Generally, the two main virulence factors in ETEC that lead to diarrhea in humans are colonization factors and enterotoxins [58].

ETEC first adhere to the small intestine epithelial cells via surface structures and then secrete the enterotoxins. Colonization plays a fundamental role in the initial step of the pathogenesis mechanism of ETEC. ETEC engage with small bowel epithelial cells by various plasmid-encoded colonization factor ( $\mathrm{CFs}$ ) genes encoding fimbrial, non-fimbrial and fibrillar structures [59]. Among many CFs, CFA/I, CFA/II, and CFA/IV are the main factors to mediate the colonization of ETEC and have been highly detected in ETEC isolated from clinical samples. Other proteinaceous fimbrial and non-fimbrial structures include coli surface antigens (CS) such as CS1-CS6, type 1 fimbriae (fimH), E. coli common pili $(\operatorname{ecp} A)$ [60], autotransporter proteins such as the Etp group of proteins, and EatA (a member of SAPTE family). Flagella promote the initial attachment, adhesin, and colonization of ETEC to the host intestinal epithelial cells [61]. The EtpA secreted by ETEC is a glycoprotein containing $\mathrm{N}$-acetylgalactosamine (NAG). NAG also presents as the sugar moiety on A blood group glycans. Therefore, ETEC contributes to a more severe diarrheal disease among humans with Type A blood [62].

The most prominent and effective virulence factor of ETEC is the secretion of enterotoxins. Two types of enterotoxins, heat-stable toxins (STs) and heat-labile toxins (LTs), are secreted by ETEC and activate cyclic nucleotide production, contributing to intestinal net water, salt, and fluid loss, causing secretory diarrhea in humans and animals. LTs, STs, or a combination of both toxins might be expressed by ETEC strains [63]. Genes encoding enterotoxins are located on both plasmids and the chromosome (prophages), which can be transferred among the different E. coli pathotypes. A 72 amino-acid (aa) protein (as the toxin precursor) is synthesized, of which a 19-18 aa region is released as the active form of the heat-stable toxin. These toxins are divided into STI and STII encoded by est $A$ and est $B$ genes, respectively located on plasmids. Considering the host species, STI is classified into STp (18 aa) and STh (19 aa) subtypes, mainly found in porcine and human ETEC strains, respectively. However, both subtypes have been detected in ETEC isolated from humans [64]. The structure of these toxins mimics the biologic function of mammalian peptides, including guanylin and uroguanylin, binds to the guanylate cyclase $\mathrm{C}$ receptor, and increases the intracellular cyclic guanosine monophosphate (cGMP) via the hydrolysis 
of guanosine triphosphate. The increase in cGMP concentration activates the protein kinase that phosphorylates the cystic fibrosis transmembrane regulatory (CFTR) channel. The activated CFTR channel inhibits ion exchange and sodium reabsorption, contributing to the release of water and salt into the intestinal lumen and thus net fluid loss, leading to watery and secretory diarrhea $[65,66]$. The putative export channel for the secretion of ST is an outer membrane protein encoded by the tolC gene. The EtpA adhesin factor gene, located on a plasmid, expresses a protein to construct a molecular bridge structure between bacteria and the host cell. Without the expression of tolC and EtpA genes, the delivery of $\mathrm{ST}$ to the target cells is not performed. These genes have also been considered the main virulence factors of ETEC [67]. Another mechanism of ST triggering diarrhea is the tight junction modulation of intestinal epithelial cells, leading to an increase in permeability by suppressing the expression of proteins and disturbing the integrity of the tight junction. In addition, ST toxins mediating the innate immune responses led to the secretion of chemokines and cytokines such as IL-6 and IL-8 [63].

Another toxin secreted by ETEC after colonization of the small intestine is a heatlabile toxin. Two types of LT have been identified, LT type I and II. LT (type I) is also categorized into LTh and LTp subtypes, detected in strains isolated from humans and pigs. However, LT II is mainly associated with strains isolated from animals and occasionally from humans [67]. LT is initially synthesized as a holotoxin in the periplasm and then released via two secretion systems: a type-II secretion system (T2SS) and outer membrane vesicles (OMV). ETEC mainly secretes LT through the OMV system. ST and LT toxins are composed of a single A subunit with enzymatic activity and a pentameric B subunit binding to the GM1 ganglioside receptor on the host cell surface [68]. The structure and pathogenesis mechanism of LT is identical to that (about $80 \%$ ) of the cholera toxin secreted by Vibrio cells. After delivery and translocation into the host cell, the A subunit induces the ADP-ribosylation factor and inhibits GS $\alpha$ GTPase activity, leading to the activation of adenylate cyclase and the increase of intracellular cyclic adenosine monophosphate (cAMP) concentrations. Higher levels of cAMP contribute to the activation of the CFTR ion channel, followed by the secretion of water and electrolytes, leading to watery diarrhea [69]. By interacting with the carbohydrate-binding sites, LT also binds to blood groups A and B determinants. LT also facilitates the ETEC pathogenesis by improving the initial adherence, intestinal colonization, and increased virulence factors expression [64]. There are other virulence factors detected in ETEC strains isolated from humans with diarrhea. Secretion of an enteroaggregative heat-stable toxin (EAST1) by ETEC, encoded by the ast gene, with a similar function to the ST toxin, leads to increased intracellular levels of cGMP. The SPATE EatA, located on a large virulence plasmid, also increases the virulence of ETEC by facilitating the LT delivery (Table 1) [70].

\section{Enteroinvasive Escherichia coli (EIEC)}

Severe mucosal and bloody diarrhea with abdominal cramps and fever are typical clinical features of bacillary dysentery or shigellosis caused by different species of Shigella and EIEC as invasive foodborne pathogens [13,71]. Initially known as Bacillus dysenteriae, Shigella was previously characterized in 1897 by Kiyoshi Shiga in Japan after a severe epidemic causing more than 91,000 cases, with $20 \%$ mortality [72]. Fifty years later, EIEC was discovered and characterized with the same genetic, pathogenic, and biochemical properties as were observed for Shigella. Thus, they may be categorized in a single pathovar. However, a considerable distinction is still maintained regarding the clinical significance of Shigella species [1,73]. EIEC and Shigella are unable to ferment lactose, are non-motile, and lysine decarboxylase negative. These properties are considered to differentiate Shigella species and EIEC from other bacteria [74]. EIEC differs from other pathovars of E. coli because it is an obligate intracellular pathogen with neither adherence nor flagella factors [71]. Shigella comprise four species, including S. sonnei, S. flexneri, S. boydii and S. dysenteriae, which are responsible for varying degrees of diarrhea and acute intestinal and 
extra-intestinal diseases in humans $[73,75,76]$. EIEC strains primarily elicit watery diarrhea and cause invasive inflammatory colitis [77].

EIEC/Shigella infection commences with the penetration of the pathogen into the epithelial cells in the colon, passing through the microfold cells and reaching the underlying submucosa by a transcytosis mechanism $[78,79]$. The disruption and damage of tight junctions caused by inflammation also give EIEC access to the underlying submucosa [80]. EIEC is taken up by macrophages, where it lyses the endocytic vacuole and escapes from the phagosome. Following the release from dead macrophages, EIEC invades the basolateral sides of the colonocytes, survives and multiplicates intracellularly, moves directionally through the cytoplasm, and extends into the adjacent epithelial cell [13]. The virulence of this pathogen is primarily due to $220-\mathrm{kb}$ plasmid-encoding virulence factors including the T3SS complex, chaperones, transcriptional regulators, translocators, and more than 25 effector proteins [4]. A T3SS needle, strongly required for the invasion, apoptosis of macrophages, and cell survival, is encoded on the mxi-spa locus of the virulence plasmid [11]. Before the invasion, the adhesion of EIEC to the epithelial cells is mediated via the binding of proteins encoded by the IpaBCD complex and IpaB genes to the $\alpha_{1} \beta_{5}$ integrin and hyaluronan CD44 receptors, respectively. Membrane ruffling and epithelial cell cytoskeleton reorganization are mediated by $\operatorname{IpaA}, \operatorname{IpaC}, \operatorname{IpgB1}, \operatorname{IpgD}$, and virA to provide pathogen uptake [81]. IpaH7.8, IpaB, IpaD, and IpaC have also been implicated in phagosome escape [82]. VirG nucleates actin by inducing the acquisition of $\mathrm{N}$-WASP, contributing to ARP2/3 formation and mediated unipolar actin tail formation on the surface of the bacteria [83]. IpaC also activates SRC-family protein kinases to recruit the ARP2/3 complex at the site of the bacterial contact and induces actin polymerization to form a ruffle for bacterial entry. IpgB1 as mimicry of RhoG also promotes ruffle formation by the activation of RAC1. Actin microfilaments and their polymerization provide the propulsive forces needed for the directed movement of the pathogen throughout the host cell cytoplasm [80]. EIEC provides host cell integrity and survival in the early stages of infection by inhibiting intestinal epithelial cell detachment and turnover utilizing protein effectors $O s p E$ and $I p a B$, respectively. Some effectors, including $\operatorname{Vir} A$, IpaA, and $\operatorname{Ipg} D$, destabilize microtubules and actin and mediate the blockage of death in host cells to promote colonization and maintain its replicative niche $[4,82]$.

Once localized in the epithelial cell cytoplasm, EIEC suppresses the host immune response and counteracts the immune defense system by using protein effectors to persist and survive inside the colonocytes [84]. OspF and $O s p G$ inhibit the activation and gene transcription of NF-KB. IpaH $\mathrm{H}_{9.8}$ and $\mathrm{OspB}$ also suppress the expression of inflammatory cytokine levels such as interleukin-8. Other effectors, including OspZ, OspI, and $\mathrm{IpaH}_{4.5}$, also help EIEC downregulate and dampen the inflammatory responses [82]. Moreover, effectors IcsB and VirA promote host-cell-autophagy-mediated degradation in EIEC by sequestering the VirG and destabilizing microtubules, respectively [84]. Common clinical symptoms of watery diarrhea in EIEC and Shigella infections have been attributed to the additional virulence factors, including Shigella enterotoxins 1 and 2 encoded by ShET1 and ShET2 genes, respectively. ShET1 is located on the chromosome and a pathogenicity island, whereas ShET2 has been found in a virulence plasmid. Both enterotoxins contribute to secretary intestinal activity. ShET2 induces inflammation in the host intestinal epithelial cells [85]. Moreover, other toxins encoded by virulence factor genes such as Pic, SepA, $\operatorname{Sig} A$, and Sat are expressed and secreted in EIEC and Shigella species. Pic, encoded by chromosome locus, regulates ShET1 expression [80]. SepA and Pic toxin genes belong to the serine protease autotransporters of the Enterobacteriaceae (SPATEs) family toxin. SPATEs are protease-based toxins released by autotransporter pathways and secreted usually by pathogenic E. coli and Shigella species [86]. The SigA-encoded cytotoxin contributes to intestinal fluid accumulation in the EIEC or Shigella-infected hosts [86]. Recently, other virulence factors have also been detected and identified prevalently in EIEC and Shigella isolates, including iut A, iucB, Eat A, VirF, VirB, IpaJ, and OspC3 implicated for aerobactin synthesis, complex siderophore iron receptor, SPATE toxin, the regulation of virulence 
factor gene expression, the control of virulence factor gene synthesis, the inhibition of the host cell trafficking membrane, and the inhibition of inflammasomes, respectively (Table 1) [72,79].

\section{Enteroaggregative Escherichia coli (EAEC)}

EAEC has been considered an emerging foodborne pathogen primarily associated with persistent and acute childhood diarrhea and growth retardation in developed and developing countries [13]. Moreover, EAEC is the second leading cause of acute and persistent travelers' diarrhea after ETEC in developed and developing nations, and one of the major causes of enteric infections in patients with HIV / AIDS [4,52]. Other symptoms of EAEC infection include vomiting, nausea, borborygmi, anorexia, and tenesmus $[87,88]$. As mentioned before, a hybrid strain of EAEC/STEC (serotype O104: H4) caused a large outbreak in 2011 in Germany, resulting in more than 4300 diarrhea cases and 50 deaths [89]. Several studies indicated that EAEC has the potential for efficient gut inflammation and enteric colonization, which might intensify the effects of other pathogenic bacterial virulence strategies [7]. EAEC often causes watery diarrhea, occasionally accompanied by blood or mucus. EAEC colonizes the mucosa of small and large bowels, contributing to mild to severe inflammation in the colon [90]. Traditionally, EAEC has been characterized by a "stacked-brick" pattern adherence to Hep-2 cells. Due to the heterogenicity of EAEC, the pathogenic mechanisms of this pathogen are very complicated. EAEC pathogenesis involves three steps: adherence to the intestinal epithelium via adherence aggregative fimbriae, biofilm formation, and secretion of toxins, mucosal inflammation, and cytotoxic damages $[32,88,91]$.

The virulence factors of EAEC are encoded on a family of virulence plasmids, the plasmid of aggregative adherence called pAA, and pathogenicity islands distributed throughout the chromosome [92]. AggR is the main virulence factor regulator of EAEC. It is a member of a bacterial transcriptional regulator family, $\mathrm{AraC}$, and is located on the pAA plasmid to control the expression of plasmid-borne and chromosomal virulence factorencoded genes [93]. Epidemiological studies showed a significant association between the presence of the AggR gene, diarrheal diseases, and the concentrations of fecal cytokines in patients with diarrhea infected with EAEC strains [94-96]. Therefore, EAEC strains are divided into typical, carrying AggR, and AggR-regulated virulence factors and atypical EAEC, lacking the AggR regulon. The first stage of EAEC pathogenesis is the attachment and adherence to the intestinal mucosal cells [97]. The aggregative adherence of EAEC is associated with the aggregative adhesion fimbria (AAF), which is encoded by AAF genes [97]. Moreover, the initial attachment of EAEC to the epithelial cells is facilitated by AAFs. Five variants of AAFs have been identified, including AAF/I-V encoded by $\operatorname{agg} A$, aaf $A, \operatorname{agg} 3 A, \operatorname{agg} 4 A$, and $\operatorname{agg} 5 A$, respectively. All of them are located on pAA. AAF genes have exclusively been detected in EAEC pathotypes [90]. The adherence mediated by AAFs and flagellin also induces cytokine responses [98]. The isoelectric point of AAFs is relatively high (pI: 8.9-9.4) compared with other adhesins. Throughout the gut ( $\mathrm{pH}$ : 6-7.4), the AAFs bear a high positive charge [97]. Regarding the negative charge of lipopolysaccharide on the surface of gram-negative bacteria, an extension of AAFs away from the cell surface is mediated with the help of the secretion of a protein called dispersin. Dispersin is encoded by the aap gene located on pAA and can mask the negative charge conferred by lipopolysaccharides [99]. This protein counteracts excessive aggregation and causes the dispersion of EAEC across the mucosal epithelial cells. Other, less critical factors associated with EAEC adherence are alternative fimbrial structures, including type-IV pili [100]. Biofilm formation is another pathogenic mechanism of EAEC, and it is entirely distinct from that mediated by non-pathogenic E. coli. A type-VI secretion system (T6SS) encoded by aai $A-Y$ genes, located on a pathogenicity island identified on the chromosome and activated by AggR, mediates biofilm formation in EAEC. However, aai $\mathrm{A}$ and aaiC genes have more commonly been found in typical EAEC strains worldwide [90,101]. 
The final stage of EAEC pathogenesis is toxin secretion, causing several effects, including enlarged crypt opening, microvillus vesiculation, and epithelial cell extrusion [88]. These putative toxins include a plasmid-encoded toxin, a protein involved in intestinal colonization, a Shigella extracellular enterotoxin, a secreted autotransporter toxin, and an enteroaggregative heat-stable toxin, which are encoded by the pet, pic, $\operatorname{sig} A, \operatorname{sep} A, \operatorname{sat}$, and ast $A$ genes, respectively [90]. The $\operatorname{sig} A$ and pic genes are located on pathogenicity islands, and the other toxin genes are localized on pAA [102]. A thick mucus layer surrounds the EAEC biofilms, and the bacteria penetrate it through the secretion of the SPATE pic toxin with mucolytic activity [90]. Shigella extracellular enterotoxins (ShET1) are cytotoxin, enterotoxin, and IgA protease like homologues inducing intestinal cyclic GMP (cGMP) and cAMP-mediated secretion. This toxin has also been found in EAEC/STEC hybrid strains [88,103]. Pet, a $108 \mathrm{kDa}$ protein belonging to the SPATE family, mediates the actinbinding protein fodrin, induces exfoliation, disrupts the actin skeleton, is trafficked through the endoplasmic reticulum, and induces the entry into the host cell. Pet also functions as a cytotoxin and heat-labile enterotoxin [104]. Sat, a SPATE toxin with cytotoxic and enterotoxic activities, impairs the tight junction and mediates autophagy in the epithelial cells. The enteroaggregative heat-stable toxin has mechanistic and physical similarities to the enterotoxin STa secreted by ETEC (Table 1) [105].

\section{Diffusely Adherent Escherichia coli (DAEC)}

DAEC is identified as a heterogenous pathotype of E. coli characterized by a diffuse pattern on Hep-2 and HeLa cells [88]. DAEC is associated with diarrhea in children between the ages of 1.5 and 5 years, urinary tract infection (UTI) in adults, pregnancy complications, and part of the intestinal commensal microflora in adults and children [106]. Watery diarrhea caused by DAEC can become more persistent in younger children. Adults are asymptomatic carriers of DAEC strains contributing to some chronic inflammatory intestinal diseases, including Crohn's, coeliac, and inflammatory bowel diseases [107]. It has been shown that DAEC strains belong to the phylogenetic group B2, and it is worth noting that this phylogenetic group is predominant among the human commensal E. coli strains $[32,88,108]$. Despite the isolation of this strain from stools and duodenal cultures, none of the adult patients developed diarrhea [88]. The pathogenesis of DAEC starts with the attachment of the pathogen to specific host cells. The attachment of DAEC strains onto the urinary tract and enteric epithelial cells allows them to resist clearance by micronutrition and peristalsis, respectively [109]. The attachment also allows DAEC to interact with the host cell, release and deliver toxins, and trigger signaling events in host cells. DAEC attaches and adhere to the host cells using non-classical patterns and is mediated by Afa/Dr adhesins [110].

An important step in DAEC infection is the specific colonization of the small bowel mediated by the Afa/Dr family of adhesins, including the two main classes of adhesins presented on the surface of the pathogen: fimbrial adhesins (including linear polymers) and afimbrial adhesins (homotrimers or single proteins) [111-113]. Afa/Dr adhesins include Dr, DrII, AfaE/I-III, AfaE-V, NFA-I, and F1845 adhesins. Afa, Dr, and F1845 adhesins are encoded by afaA-E, DraA-E, and daaA-E genes, respectively [107,114]. F1845 and Dr adhesins bind to the decay-accelerating factor (DAF), a molecule expressed and found on the apical surface of urinary and intestinal epithelial cells, inducing cytoskeleton rearrangement and destroying microvilli $[11,32,88]$. The increased levels of DAF expression caused by the binding of Afa/Dr adhesins in patients with Crohn's disease (CD) may contribute to the inflammation [110]. Some Afa/Dr adhesins can also bind to the epithelial cell surface receptor human carcinoembryonic antigen-related cell adhesion molecule (CEACAM), resulting in CDC42 activation, CEACAM aggregation at the site of bacterial adhesion, brush border microvilli effacement, and the mediation of a process leading to the microfilament-independent, microtubule- and lipid-raft-dependent internalization of the bacterial pathogen. These processes are thought to play a major role in the infection of intestinal epithelial cells by DAEC strains [115]. Moreover, Dr adhesins bind to type-IV 
collagen, necessary for DAEC-mediated urinary tract infections $[88,115]$. The interaction between Afa/Dr adhesins, flagella, and DAF receptors mediates IL-8 secretion and promotes the transmigration of polymorphonuclear neutrophils (PMNs). This causes DAF upregulation on the epithelial cell surface, providing more adhesion receptors $[107,112]$. The interaction between PMNs and Afa/Dr adhesins accelerates PMN-associated apoptosis and decreases the rate of phagocytosis mediated by PMNs. Across the epithelial cells, DAEC strains also induce the expression of MICA, which is potentially responsible for mediating inflammatory bowel disease (IBD) $[112,116]$.

Although the pathogenesis of DAEC strains is mainly mediated through Afa/Dr adhesins, some SPATE toxins are secreted by this pathotype [112]. Afa/Dr DAEC strains release two main classes of SPATE toxins: class I, with cytotoxic activity against epithelial cells, including a secreted autotransporter toxin, a plasmid-encoded toxin, an extracellular serine protease, and $\operatorname{sig} A$ toxins, encoded by sat, pet, EspP, and $\operatorname{sig} A$ genes, respectively; class II, which are not cytotoxic and consist of a protein involved in intestinal colonization encoded by the pic gene $[12,88,115]$. In addition, other virulence factors, including type-I pili, pilus adhesin and enteroaggregative heat-stable toxins encoded by pap, fim, and ast $A$ genes, respectively, have been recently detected in DAEC strains (Table 1) [117].

\section{Adherent Invasive Escherichia coli (AIEC)}

AIEC is one of the most important causative agents of idiopathic inflammatory disorders, including IBD and CD, and primarily affect the human small bowel [118]. However, this pathotype may also be present as part of the normal microbiota of the human gut in healthy individuals and does not cause any disease [119]. No single distinct agent is defined as the leading cause of idiopathic IBD [120,121]. In addition to AIEC, other enteric pathogens have been reported to be involved in IBD and CD, including Campylobacter species, Mycobacterium paratuberculosis, and Cytomegalovirus [122,123]. The AIEC pathotype is an enteric pathogen able to adhere to and invade the intestinal epithelial cell layer and multiply within macrophages and epithelial cells. No particular virulence factors found in other E. coli pathotypes have been determined in AIEC strains [124,125]. AIEC pathogenesis consists of three stages: adhesion, invasion, and multiplication within the epithelial host cells. Initially, AIEC requires the adhesion to the epithelial host cells in the ileum, using the CAECAM6 expressed on these cells. Notably, the expression levels of CAECAM6 in CD patients is increased due to the stimulation of TNF- $\alpha$ production, causing intestinal inflammation by the colonization of AIEC [126]. Several virulence factors, such as outer membrane vesicles, outer membrane proteins, and long polar fimbriae, are expressed and utilized by AIEC strain after the adhesion to the epithelial host cells to mediate invasion, infect, and replicate within the macrophages [124,127].

Several virulence factors and associated encoding genes have been identified to play a role in the pathogenic interaction with the intestinal mucosa. Higher levels of expression of genes encoding virulence factors involved in adhesion, invasion, and survival encoding were detected in AIEC isolated from patients with CD, IBD, and ulcerative colitis [128-130]. Virulence factors present in AIEC isolated from patients with intestinal disorders include the adhesive subunit of type- 1 fimbriae, the polypeptide stress response protein, the invasion protein $i b e A$, the invasion plasmid antigen, and virulence factors involved in ferric yersiniabactin uptake and capsule synthesis encoded by fim $H$, yjaA, ibe $A, i p a H$, fyuA, and kpsMT II genes, respectively [114,131,132]. AIEC strains have been considered a new therapeutic target for treating patients with IBD and CD [123]. However, several aspects of its pathogenesis are unknown and more genomic investigations, especially to determine the virulence factor-encoding genes, are required (Table 1) [118,127,129].

\section{Conclusions}

Enteric E. coli pathotypes display a high diversity of pathogenicity mechanisms and virulence factors profiles. They remain a significant concern in public health and food safety. The evolution of enteric $E$. coli pathotypes has contributed to the emergence of distinct $E$. coli 
pathotypes capable of toxin secretion, aggregative colonization, multiplying in the gastrointestinal tract, and damaging different environments through the adaptation of key genetic elements, resulting in the formation of new pathotypes [133]. The emergence of new E. coli pathotypes such as the hybrid EAEC/STEC (E. coli serotype O104: H4) strain that caused fatal outbreaks throughout Europe shows the importance of having a surveillance system in place. As food, water, animals, and people are potential vectors of enteric pathogenic $E$. coli transmission and contamination [5], such surveillance systems should be embedded in one-health approaches/networks. A wide range of functions including protein synthesis, specific gene transcription, the secretion of diverse micro/macro-molecules and ions, cytoskeleton rearrangement, apoptosis, autophagy, mitochondrial activities, cell division, and signal transduction in epithelial intestinal and extraintestinal host cells are affected by enteric $E$. coli pathotypes. This involves a broad spectrum of virulence factors encoded by specific gene clusters on the chromosome or mobile genetics elements. Therefore, for an optimal surveillance, new technologies such as high-throughput sequencing are required to gather precise information about the virulence profiles of E. coli pathotypes [134,135]. In addition, a comprehensive investigation of the role of E. coli pathotype virulence factors in pathogenesis will facilitate the development of novel therapeutics, the improvement of the design of effective vaccines, and the prevention of a further spreading of these diverse and widespread pathogens.

Author Contributions: Conceptualization, B.P., W.M.B. and J.W.A.R.; writing-original draft preparation, B.P.; writing-review and editing, W.M.B., B.P. and J.W.A.R. All authors have read and agreed to the published version of the manuscript.

Funding: This research received no external funding.

Institutional Review Board Statement: Not applicable.

Informed Consent Statement: Not applicable.

Data Availability Statement: We confirm that all data supporting the findings of this study are available within the article.

Conflicts of Interest: The authors declare no conflict of interest.

\section{References}

1. Escobar-Paramo, P.; Giudicelli, C.; Parsot, C.; Denamur, E. The evolutionary history of Shigella and enteroinvasive Escherichia coli revised. J. Mol. Evol. 2003, 57, 140-148. [CrossRef]

2. Tenaillon, O.; Skurnik, D.; Picard, B.; Denamur, E. The population genetics of commensal Escherichia coli. Nat. Rev. Microbiol. 2010, 8, 207-217. [CrossRef]

3. Nash, J.H.; Villegas, A.; Kropinski, A.M.; Aguilar-Valenzuela, R.; Konczy, P.; Mascarenhas, M.; Ziebell, K.; Torres, A.G.; Karmali, M.A.; Coombes, B.K. Genome sequence of adherent-invasive Escherichia coli and comparative genomic analysis with other E. coli pathotypes. BMC Genom. 2010, 11, 1-15. [CrossRef]

4. Donnenberg, M. Escherichia coli: Pathotypes and Principles of Pathogenesis; Academic Press: New York, NY, USA, 2013.

5. Yang, S.-C.; Lin, C.-H.; Aljuffali, I.A.; Fang, J.-Y. Current pathogenic Escherichia coli foodborne outbreak cases and therapy development. Arch. Microbiol. 2017, 199, 811-825. [CrossRef] [PubMed]

6. Alegbeleye, O.O.; Sant'Ana, A.S. Pathogen subtyping tools for risk assessment and management of produce-borne outbreaks. Curr. Opin. Food Sci. 2020, 32, 83-89. [CrossRef]

7. Clements, A.; Young, J.C.; Constantinou, N.; Frankel, G. Infection strategies of enteric pathogenic Escherichia coli. Gut Microbes 2012, 3, 71-87. [CrossRef] [PubMed]

8. Pakbin, B.; Akhondzadeh Basti, A.; Khanjari, A.; Azimi, L.; Karimi, A. Differentiation of stx1A gene for detection of Escherichia coli serotype O157: H7 and Shigella dysenteriae type 1 in food samples using high resolution melting curve analysis. Food Sci. Nutr. 2020, 8, 3665-3672. [CrossRef] [PubMed]

9. Wu, H.-J.; Wang, A.H.; Jennings, M.P. Discovery of virulence factors of pathogenic bacteria. Curr. Opin. Chem. Biol. 2008, 12, 93-101. [CrossRef]

10. Alegbeleye, O.O.; Singleton, I.; Sant'Ana, A.S. Sources and contamination routes of microbial pathogens to fresh produce during field cultivation: A review. Food Microbiol. 2018, 73, 177-208. [CrossRef]

11. Mainil, J. Escherichia coli virulence factors. Vet. Immunol. Immunopathol. 2013, 152, 2-12. [CrossRef] [PubMed]

12. Gomes, T.A.; Elias, W.P.; Scaletsky, I.C.; Guth, B.E.; Rodrigues, J.F.; Piazza, R.M.; Ferreira, L.C.; Martinez, M.B. Diarrheagenic Escherichia coli. Braz. J. Microbiol. 2016, 47, 3-30. [CrossRef] 
13. Kaper, J.B.; Nataro, J.P.; Mobley, H.L. Pathogenic Escherichia coli. Nat. Rev. Microbiol. 2004, 2, 123-140. [CrossRef]

14. Ochoa, T.J.; Barletta, F.; Contreras, C.; Mercado, E. New insights into the epidemiology of enteropathogenic Escherichia coli infection. Trans. R. Soc. Trop. Med. Hyg. 2008, 102, 852-856. [CrossRef]

15. Gaytán, M.O.; Martínez-Santos, V.I.; Soto, E.; González-Pedrajo, B. Type three secretion system in attaching and effacing pathogens. Front. Cell. Infect. Microbiol. 2016, 6, 129. [CrossRef]

16. Songe, M.M.; Hang'ombe, B.M.; Knight-Jones, T.J.; Grace, D. Antimicrobial resistant enteropathogenic Escherichia coli and Salmonella spp. in houseflies infesting fish in food markets in Zambia. Int. J. Environ. Res. Public Health 2017, 14, 21. [CrossRef]

17. Brück, W.M.; Kelleher, S.L.; Gibson, G.R.; Nielsen, K.E.; Chatterton, D.E.; Lönnerdal, B. rRNA probes used to quantify the effects of glycomacropeptide and $\alpha$-lactalbumin supplementation on the predominant groups of intestinal bacteria of infant rhesus monkeys challenged with enteropathogenic Escherichia coli. J. Pediatr. Gastroenterol. Nutr. 2003, 37, 273-280. [CrossRef] [PubMed]

18. Brück, W.M.; Kelleher, S.L.; Gibson, G.R.; Graverholt, G.; Lönnerdal, B.L. The effects of $\alpha$-lactalbumin and glycomacropeptide on the association of CaCo-2 cells by enteropathogenic Escherichia coli, Salmonella typhimurium and Shigella flexneri. FEMS Microbiol. Lett. 2006, 259, 158-162. [CrossRef] [PubMed]

19. Hernandes, R.T.; Elias, W.P.; Vieira, M.A.; Gomes, T.A. An overview of atypical enteropathogenic Escherichia coli. FEMS Microbiol. Lett. 2009, 297, 137-149. [CrossRef]

20. Serapio-Palacios, A.; Finlay, B.B. Dynamics of expression, secretion and translocation of type III effectors during enteropathogenic Escherichia coli infection. Curr. Opin. Microbiol. 2020, 54, 67-76. [CrossRef]

21. Xu, Y.; Bai, X.; Jin, Y.; Hu, B.; Wang, H.; Sun, H.; Fan, R.; Fu, S.; Xiong, Y. High prevalence of virulence genes in specific genotypes of atypical enteropathogenic Escherichia coli. Front. Cell. Infect. Microbiol. 2017, 7, 109. [CrossRef] [PubMed]

22. Zheng, W.; Peña, A.; Ilangovan, A.; Clark, J.N.-B.; Frankel, G.; Egelman, E.H.; Costa, T.R. Cryoelectron-microscopy structure of the enteropathogenic Escherichia coli type III secretion system EspA filament. Proc. Natl. Acad. Sci. USA 2021, 118, e2022826118. [CrossRef]

23. Platenkamp, A.; Mellies, J.L. Environment controls LEE regulation in enteropathogenic Escherichia coli. Front. Microbiol. 2018, 9 , 1694. [CrossRef]

24. Pollock, G.L. Investigating the Molecular Mechanisms of Enteropathogenic Escherichia coli Pathogenesis. Ph.D. Thesis, University of Melbourne, Melbourne, Australia, 2019.

25. Pinaud, L.; Sansonetti, P.J.; Phalipon, A. Host cell targeting by enteropathogenic bacteria T3SS effectors. Trends Microbiol. 2018, 26, 266-283. [CrossRef] [PubMed]

26. Shenoy, A.R.; Furniss, R.C.D.; Goddard, P.J.; Clements, A. Modulation of host cell processes by T3SS effectors. In Escherichia coli, a Versatile Pathogen; Springer: Cham, Switzerland, 2018; pp. 73-115.

27. Slater, S.L.; Sågfors, A.M.; Pollard, D.J.; Ruano-Gallego, D.; Frankel, G. The type III secretion system of pathogenic Escherichia coli. In Escherichia coli, a Versatile Pathogen; Current Topics in Microbiology and Immunology; Springer: Cham, Switzerland, 2018; Volume 416, pp. 51-72.

28. Ruano-Gallego, D.; Sanchez-Garrido, J.; Kozik, Z.; Núñez-Berrueco, E.; Cepeda-Molero, M.; Mullineaux-Sanders, C.; Clark, J.N.-B.; Slater, S.L.; Wagner, N.; Glegola-Madejska, I. Type III secretion system effectors form robust and flexible intracellular virulence networks. Science 2021, 371, 6534. [CrossRef]

29. Deborah Chen, H.; Frankel, G. Enteropathogenic Escherichia coli: Unravelling pathogenesis. FEMS Microbiol. Rev. 2005, 29, 83-98. [CrossRef] [PubMed]

30. Donnenberg, M.S.; Finlay, B.B. Combating enteropathogenic Escherichia coli (EPEC) infections: The way forward. Trends Microbiol. 2013, 21, 317-319. [CrossRef]

31. Hartland, E.L.; Leong, J. Enteropathogenic and enterohemorrhagic E. coli: Ecology, pathogenesis, and evolution. Front. Cell. Infect. Microbiol. 2013, 3, 15. [CrossRef]

32. Croxen, M.A.; Finlay, B.B. Molecular mechanisms of Escherichia coli pathogenicity. Nat. Rev. Microbiol. 2010, 8, 26-38. [CrossRef] [PubMed]

33. Welinder-Olsson, C.; Kaijser, B. Enterohemorrhagic Escherichia coli (EHEC). Scand. J. Infect. Dis. 2005, 37, 405-416. [CrossRef]

34. van Hoek, A.H.; van Veldhuizen, J.N.; Friesema, I.; Coipan, C.; Rossen, J.W.; Bergval, I.L.; Franz, E. Comparative genomics reveals a lack of evidence for pigeons as a main source of stx $2 \mathrm{f}$-carrying Escherichia coli causing disease in humans and the common existence of hybrid Shiga toxin-producing and enteropathogenic E. coli pathotypes. BMC Genom. 2019, 20, 271. [CrossRef]

35. Meng, J.; LeJeune, J.T.; Zhao, T.; Doyle, M.P. Enterohemorrhagic Escherichia coli. In Food Microbiology: Fundamentals and Frontiers; ASM Press: Washington, DC, USA, 2012; pp. 287-309.

36. Prado-Silva, L.; Cadavez, V.; Gonzales-Barron, U.; Rezende, A.C.B.; Sant'Ana, A.S. Meta-analysis of the effects of sanitizing treatments on Salmonella, Escherichia coli O157: H7, and Listeria monocytogenes inactivation in fresh produce. Appl. Environ. Microbiol. 2015, 81, 8008-8021. [CrossRef]

37. Posada-Izquierdo, G.; Del Rosal, S.; Valero, A.; Zurera, G.; Sant'Ana, A.; Alvarenga, V.; Pérez-Rodríguez, F. Assessing the growth of Escherichia coli O157: H7 and Salmonella in spinach, lettuce, parsley and chard extracts at different storage temperatures. J. Appl. Microbiol. 2016, 120, 1701-1710. [CrossRef]

38. Kampmeier, S.; Berger, M.; Mellmann, A.; Karch, H.; Berger, P. The 2011 German enterohemorrhagic Escherichia coli O104: H4 outbreak-The danger is still out there. In Escherichia colia a Versatile Pathog; Current Topics in Microbiology and Immunology; Springer: Cham, Switzerland, 2018; Volume 416, pp. 117-148. 
39. Zhou, K.; Ferdous, M.; de Boer, R.F.; Kooistra-Smid, A.M.; Grundmann, H.; Friedrich, A.W.; Rossen, J.W. The mosaic genome structure and phylogeny of Shiga toxin-producing Escherichia coli O104: H4 is driven by short-term adaptation. Clin. Microbiol. Infect. 2015, 21, 468.e7-468.e18. [CrossRef]

40. Joseph, A.; Cointe, A.; Mariani Kurkdjian, P.; Rafat, C.; Hertig, A. Shiga toxin-associated hemolytic uremic syndrome: A narrative review. Toxins 2020, 12, 67. [CrossRef] [PubMed]

41. Gyles, C. Shiga toxin-producing Escherichia coli: An overview. J. Anim. Sci. 2007, 85, E45-E62. [CrossRef] [PubMed]

42. Ferdous, M.; Friedrich, A.W.; Grundmann, H.; de Boer, R.F.; Croughs, P.D.; Islam, M.A.; Kluytmans-van den Bergh, M.F.; Kooistra-Smid, A.M.; Rossen, J.W. Molecular characterization and phylogeny of Shiga toxin-producing Escherichia coli isolates obtained from two Dutch regions using whole genome sequencing. Clin. Microbiol. Infect. 2016, 22, 642.e1-642.e9. [CrossRef]

43. Melton-Celsa, A.R. Shiga toxin (Stx) classification, structure, and function. Microbiol. Spectr. 2014, 2. [CrossRef] [PubMed]

44. Mauro, S.A.; Koudelka, G.B. Shiga toxin: Expression, distribution, and its role in the environment. Toxins 2011, 3, 608-625. [CrossRef]

45. Smith, J.L.; Fratamico, P.M.; Gunther IV, N.W. Shiga toxin-producing Escherichia coli. Adv. Appl. Microbiol. $2014,86,145-197$.

46. Melton-Celsa, A.; Mohawk, K.; Teel, L.; O’Brien, A. Pathogenesis of Shiga-toxin producing Escherichia coli. In Ricin and Shiga Toxins; Springer: Berlin/Heidelberg, Germany, 2011; pp. 67-103.

47. Schwidder, M.; Heinisch, L.; Schmidt, H. Genetics, toxicity, and distribution of enterohemorrhagic Escherichia coli hemolysin. Toxins 2019, 11, 502. [CrossRef]

48. Huang, C.-R.; Kuo, C.-J.; Huang, C.-W.; Chen, Y.-T.; Liu, B.-Y.; Lee, C.-T.; Chen, P.-L.; Chang, W.-T.; Chen, Y.-W.; Lee, T.-M. Host CDK-1 and formin mediate microvillar effacement induced by enterohemorrhagic Escherichia coli. Nat. Commun. 2021, 12, 1-19.

49. Barnett Foster, D. Modulation of the enterohemorrhagic E. coli virulence program through the human gastrointestinal tract. Virulence 2013, 4, 315-323. [CrossRef]

50. García-Heredia, A.; García, S.; Merino-Mascorro, J.Á.; Feng, P.; Heredia, N. Natural plant products inhibits growth and alters the swarming motility, biofilm formation, and expression of virulence genes in enteroaggregative and enterohemorrhagic Escherichia coli. Food Microbiol. 2016, 59, 124-132. [CrossRef]

51. Karpman, D.; Ståhl, A.L. Enterohemorrhagic Escherichia coli pathogenesis and the host response. Microbiol. Spectr. 2014, 2, 2-5. [CrossRef] [PubMed]

52. Beauchamp, C.S.; Sofos, J.N. Diarrheagenic Escherichia coli. In Pathogens and Toxins in Foods: Challenges and Interventions; ASM Press: Washington, DC, USA, 2009; pp. 71-94.

53. Warr, A.R.; Kuehl, C.J.; Waldor, M.K. Shiga toxin remodels the intestinal epithelial transcriptional response to Enterohemorrhagic Escherichia coli. PLoS Pathog. 2021, 17, e1009290. [CrossRef] [PubMed]

54. Krüger, A.; Lucchesi, P.; Sanso, A.M.; Etcheverría, A.I.; Bustamante, A.V.; Burgán, J.; Fernández, L.; Fernández, D.; Leotta, G.; Friedrich, A.W. Genetic characterization of Shiga toxin-producing Escherichia coli O26: H11 strains isolated from animal, food, and clinical samples. Front. Cell. Infect. Microbiol. 2015, 5, 74. [CrossRef] [PubMed]

55. Buuck, S.; Smith, K.; Fowler, R.; Cebelinski, E.; Lappi, V.; Boxrud, D.; Medus, C. Epidemiology of Enterotoxigenic Escherichia coli infection in Minnesota, 2016-2017. Epidemiol. Infect. 2020, 148, e206. [CrossRef]

56. Fleckenstein, J.M.; Kuhlmann, F.M. Enterotoxigenic Escherichia coli infections. Curr. Infect. Dis. Rep. 2019, 21, 1-9. [CrossRef]

57. Bin, P.; Tang, Z.; Liu, S.; Chen, S.; Xia, Y.; Liu, J.; Wu, H.; Zhu, G. Intestinal microbiota mediates Enterotoxigenic Escherichia coli-induced diarrhea in piglets. BMC Vet. Res. 2018, 14, 1-13. [CrossRef] [PubMed]

58. Crofts, A.A.; Giovanetti, S.M.; Rubin, E.J.; Poly, F.M.; Gutiérrez, R.L.; Talaat, K.R.; Porter, C.K.; Riddle, M.S.; DeNearing, B.; Brubaker, J. Enterotoxigenic E. coli virulence gene regulation in human infections. Proc. Natl. Acad. Sci. USA 2018, 115, E8968-E8976. [CrossRef] [PubMed]

59. Bhakat, D.; Mondal, I.; Chatterjee, N. EatA, a non-classical virulence factor, of Enterotoxigenic Escherichia coli (ETEC) is modulated by the host factors during pathogenesis. Int. J. Infect. Dis. 2020, 101, 3-4. [CrossRef]

60. Hazen, T.H.; Michalski, J.; Luo, Q.; Shetty, A.C.; Daugherty, S.C.; Fleckenstein, J.M.; Rasko, D.A. Comparative genomics and transcriptomics of Escherichia coli isolates carrying virulence factors of both enteropathogenic and enterotoxigenic E. coli. Sci. Rep. 2017, 7, 1-17.

61. Rasko, D.A.; Del Canto, F.; Luo, Q.; Fleckenstein, J.M.; Vidal, R.; Hazen, T.H. Comparative genomic analysis and molecular examination of the diversity of enterotoxigenic Escherichia coli isolates from Chile. PLoS Negl. Trop. Dis. 2019, 13, e0007828. [CrossRef] [PubMed]

62. Kumar, P.; Kuhlmann, F.M.; Chakraborty, S.; Bourgeois, A.L.; Foulke-Abel, J.; Tumala, B.; Vickers, T.J.; Sack, D.A.; DeNearing, B.; Harro, C.D. Enterotoxigenic Escherichia coli-blood group A interactions intensify diarrheal severity. J. Clin. Investig. 2018, 128, 3298-3311. [CrossRef]

63. Mirhoseini, A.; Amani, J.; Nazarian, S. Review on pathogenicity mechanism of enterotoxigenic Escherichia coli and vaccines against it. Microb. Pathog. 2018, 117, 162-169. [CrossRef]

64. Turunen, K.; Antikainen, J.; Lääveri, T.; Kirveskari, J.; Svennerholm, A.-M.; Kantele, A. Clinical aspects of heat-labile and heat-stable toxin-producing enterotoxigenic Escherichia coli: A prospective study among Finnish travellers. Travel Med. Infect. Dis. 2020, 38, 101855. [CrossRef]

65. Wang, H.; Zhong, Z.; Luo, Y.; Cox, E.; Devriendt, B. Heat-stable enterotoxins of enterotoxigenic Escherichia coli and their impact on host immunity. Toxins 2019, 11, 24. [CrossRef] 
66. Vidal, R.M.; Muhsen, K.; Tennant, S.M.; Svennerholm, A.-M.; Sow, S.O.; Sur, D.; Zaidi, A.K.; Faruque, A.S.; Saha, D.; Adegbola, R. Colonization factors among enterotoxigenic Escherichia coli isolates from children with moderate-to-severe diarrhea and from matched controls in the Global Enteric Multicenter Study (GEMS). PLoS Negl. Trop. Dis. 2019, 13, e0007037. [CrossRef]

67. Duan, Q.; Xia, P.; Nandre, R.; Zhang, W.; Zhu, G. Review of newly identified functions associated with the heat-labile toxin of enterotoxigenic Escherichia coli. Front. Cell. Infect. Microbiol. 2019, 9, 292. [CrossRef]

68. Rodrigues, J.F.; Lourenço, R.F.; Maeda, D.L.N.F.; de Jesus Cintra, M.; Nakao, N.; Mathias-Santos, C.; Luiz, W.B.; de Souza Ferreira, L.C. Strain-specific transcriptional and posttranscriptional regulation of heat-labile toxin expression by enterotoxigenic Escherichia coli. Braz. J. Microbiol. 2020, 51, 455-465. [CrossRef]

69. Subramenium, G.A.; Sabui, S.; Marchant, J.S.; Said, H.M.; Subramanian, V.S. Enterotoxigenic Escherichia coli heat labile enterotoxin inhibits intestinal ascorbic acid uptake via a cAMP-dependent NF-кB-mediated pathway. Am. J. Physiol. Gastrointest. Liver Physiol. 2019, 316, G55-G63. [CrossRef]

70. von Mentzer, A.; Blackwell, G.A.; Pickard, D.; Boinett, C.J.; Joffré, E.; Page, A.J.; Svennerholm, A.-M.; Dougan, G.; Sjöling, Å. Long-read-sequenced reference genomes of the seven major lineages of enterotoxigenic Escherichia coli (ETEC) circulating in modern time. Sci. Rep. 2021, 11, 1-16.

71. Van den Beld, M.; Reubsaet, F. Differentiation between Shigella, enteroinvasive Escherichia coli (EIEC) and noninvasive Escherichia coli. Eur. J. Clin. Microbiol. Infect. Dis. 2012, 31, 899-904. [CrossRef]

72. Lagerqvist, N.; Löf, E.; Enkirch, T.; Nilsson, P.; Roth, A.; Jernberg, C. Outbreak of gastroenteritis highlighting the diagnostic and epidemiological challenges of enteroinvasive Escherichia coli, County of Halland, Sweden, November 2017. Eurosurveillance 2020, 25, 1900466. [CrossRef] [PubMed]

73. Pakbin, B.; Didban, A.; Monfared, Y.K.; Mahmoudi, R.; Peymani, A.; Modabber, M.R. Antibiotic susceptibility and genetic relatedness of Shigella species isolated from food and human stool samples in Qazvin, Iran. BMC Res. Notes 2021, 14, 1-6. [CrossRef] [PubMed]

74. $\quad$ van den Beld, M.J.; Warmelink, E.; Friedrich, A.W.; Reubsaet, F.A.; Schipper, M.; de Boer, R.F.; Notermans, D.W.; Petrignani, M.W.; van Zanten, E.; Rossen, J.W. Incidence, clinical implications and impact on public health of infections with Shigella spp. and entero-invasive Escherichia coli (EIEC): Results of a multicenter cross-sectional study in the Netherlands during 2016-2017. BMC Infect. Dis. 2019, 19, 1-12. [CrossRef] [PubMed]

75. Schnupf, P.; Sansonetti, P.J. Shigella pathogenesis: New insights through advanced methodologies. Microbiol. Spectr. 2019, 7, 7-2. [CrossRef]

76. van den Beld, M.J.; Reubsaet, F.A.; Pijnacker, R.; Harpal, A.; Kuiling, S.; Heerkens, E.M.; Hoeve-Bakker, B.; Noomen, R.C.; Hendriks, A.C.; Borst, D. A multifactorial approach for surveillance of Shigella spp. and entero-invasive Escherichia coli is important for detecting (inter) national clusters. Front. Microbiol. 2020, 11, 2535. [CrossRef]

77. Parsot, C. Shigella spp. and enteroinvasive Escherichia coli pathogenicity factors. FEMS Microbiol. Lett. 2005, 252, 11-18. [CrossRef]

78. Torres, A.G. Current aspects of Shigella pathogenesis. Rev. Latinoam. Microbiol. 2004, 46, 89-97.

79. Hendriks, A.C.; Reubsaet, F.A.; Kooistra-Smid, A.M.; Rossen, J.W.; Dutilh, B.E.; Zomer, A.L.; van den Beld, M.J. Genome-wide association studies of Shigella spp. and Enteroinvasive Escherichia coli isolates demonstrate an absence of genetic markers for prediction of disease severity. BMC Genom. 2020, 21, 1-12. [CrossRef] [PubMed]

80. Pasqua, M.; Michelacci, V.; Di Martino, M.L.; Tozzoli, R.; Grossi, M.; Colonna, B.; Morabito, S.; Prosseda, G. The intriguing evolutionary journey of enteroinvasive E. coli (EIEC) toward pathogenicity. Front. Microbiol. 2017, 8, 2390. [CrossRef] [PubMed]

81. Cowley, L.A.; Oresegun, D.R.; Chattaway, M.A.; Dallman, T.J.; Jenkins, C. Phylogenetic comparison of enteroinvasive Escherichia coli isolated from cases of diarrhoeal disease in England, 2005-2016. J. Med. Microbiol. 2018, 67, 884-888. [CrossRef]

82. Belotserkovsky, I.; Sansonetti, P.J. Shigella and enteroinvasive Escherichia coli. In Escherichia coli, a Versatile Pathogen; Springer: Cham, Switzerland, 2018; pp. 1-26.

83. Farajzadeh-Sheikh, A.; Savari, M.; Ahmadi, K.; Nave, H.H.; Shahin, M.; Afzali, M. Distribution of Genes Encoding Virulence Factors and the Genetic Diversity of Enteroinvasive Escherichia coli (EIEC) Isolates from Patients with Diarrhea in Ahvaz, Iran. Infect. Drug Resist. 2020, 13, 119. [CrossRef] [PubMed]

84. Bona, M.; Medeiros, P.H.; Santos, A.K.; Freitas, T.; Prata, M.; Veras, H.; Amaral, M.; Oliveira, D.; Havt, A.; Lima, A.Â. Virulencerelated genes are associated with clinical and nutritional outcomes of Shigella/Enteroinvasive Escherichia coli pathotype infection in children from Brazilian semiarid region: A community case-control study. Int. J. Med. Microbiol. 2019, 309, 151-158. [CrossRef]

85. Penzel, A.; Schützler, K.; Dröge, J.; Mellmann, A.; Ehricht, R.; Engelmann, I.; Braun, S.D.; Schleenvoigt, B.T.; Löffler, B.; Rödel, J Rapid culture-based identification of Shiga toxin-producing Escherichia coli and Shigella spp./Enteroinvasive E. coli using the eazyplex ${ }^{\circledR}$ EHEC complete assay. Eur. J. Clin. Microbiol. Infect. Dis. 2020, 39, 151-158. [CrossRef]

86. Moosavian, M.; Ghaderiyan, G.H.; Shahin, M.; Navidifar, T. First investigation of the presence of SPATE genes in Shigella species isolated from children with diarrhea infection in Ahvaz, southwest Iran. Infect. Drug Resist. 2019, 12, 795. [CrossRef] [PubMed]

87. Dutta, S.; Guin, S.; Ghosh, S.; Pazhani, G.P.; Rajendran, K.; Bhattacharya, M.K.; Takeda, Y.; Nair, G.B.; Ramamurthy, T. Trends in the prevalence of diarrheagenic Escherichia coli among hospitalized diarrheal patients in Kolkata, India. PLoS ONE 2013, 8, e56068. [CrossRef] [PubMed]

88. Croxen, M.A.; Law, R.J.; Scholz, R.; Keeney, K.M.; Wlodarska, M.; Finlay, B.B. Recent advances in understanding enteric pathogenic Escherichia coli. Clin. Microbiol. Rev. 2013, 26, 822-880. [CrossRef] 
89. Rogawski, E.T.; Guerrant, R.L.; Havt, A.; Lima, I.F.; Medeiros, P.H.; Seidman, J.C.; McCormick, B.J.; Babji, S.; Hariraju, D.; Bodhidatta, L. Epidemiology of enteroaggregative Escherichia coli infections and associated outcomes in the MAL-ED birth cohort. PLoS Negl. Trop. Dis. 2017, 11, e0005798. [CrossRef]

90. Jenkins, C. Enteroaggregative Escherichia coli. In Escherichia coli, a Versatile Pathogen; Springer: Cham, Switzerland, 2018; pp. 27-50.

91. Boisen, N.; Østerlund, M.T.; Joensen, K.G.; Santiago, A.E.; Mandomando, I.; Cravioto, A.; Chattaway, M.A.; Gonyar, L.A.; Overballe-Petersen, S.; Stine, O.C. Redefining enteroaggregative Escherichia coli (EAEC): Genomic characterization of epidemiological EAEC strains. PLoS Negl. Trop. Dis. 2020, 14, e0008613. [CrossRef]

92. Nataro, J.P. Enteroaggregative Escherichia coli pathogenesis. Curr. Opin. Gastroenterol. 2005, 21, 4-8.

93. Guerrieri, C.G.; Pereira, M.F.; Galdino, A.C.M.; Santos, A.L.S.D.; Elias, W.P.; Schuenck, R.P.; Spano, L.C. Typical and atypical enteroaggregative Escherichia coli are both virulent in the Galleria mellonella model. Front. Microbiol. 2019, 10, 1791. [CrossRef]

94. Bamidele, O.; Jiang, Z.-D.; Dupont, H. Occurrence of putative virulence-related genes, aatA, aggR and aaiC, of Enteroaggregative Escherichia coli (EAEC) among adults with travelers' diarrhea acquired in Guatemala and Mexico. Microb. Pathog. 2019, 128, 97-99. [CrossRef]

95. Yasir, M.; Icke, C.; Abdelwahab, R.; Haycocks, J.R.; Godfrey, R.E.; Sazinas, P.; Pallen, M.J.; Henderson, I.R.; Busby, S.J.; Browning, D.F. Organization and architecture of AggR-dependent promoters from Enteroaggregative Escherichia coli. Mol. Microbiol. 2019, 111, 534-551. [CrossRef]

96. Mandomando, I.; Vubil, D.; Boisen, N.; Quintó, L.; Ruiz, J.; Sigaúque, B.; Nhampossa, T.; Garrine, M.; Massora, S.; Aide, P. Escherichia coli ST131 clones harbouring AggR and AAF/V fimbriae causing bacteremia in Mozambican children: Emergence of new variant of fimH27 subclone. PLoS Negl. Trop. Dis. 2020, 14, e0008274. [CrossRef] [PubMed]

97. Dias, R.C.; Tanabe, R.H.; Vieira, M.A.; Cergole-Novella, M.C.; Dos Santos, L.F.; Gomes, T.A.; Elias, W.P.; Hernandes, R.T. Analysis of the virulence profile and phenotypic features of typical and atypical enteroaggregative Escherichia coli (EAEC) isolated from diarrheal patients in Brazil. Front. Cell. Infect. Microbiol. 2020, 10, 144. [CrossRef] [PubMed]

98. Alvestegui, A.; Olivares-Morales, M.; Muñoz, E.; Smith, R.; Nataro, J.P.; Ruiz-Perez, F.; Farfan, M.J. TLR4 participates in the inflammatory response induced by the AAF/II fimbriae from enteroaggregative Escherichia coli on intestinal epithelial cells. Front. Cell. Infect. Microbiol. 2019, 9, 143. [CrossRef] [PubMed]

99. Moraes, C.T.; Longo, J.; Silva, L.B.; Pimenta, D.C.; Carvalho, E.; Morone, M.S.; da Rós, N.; Serrano, S.M.; Santos, A.C.M.; Piazza, R.M. Surface protein dispersin of enteroaggregative Escherichia coli binds plasminogen that Is converted Into active plasmin. Front. Microbiol. 2020, 11, 1222. [CrossRef]

100. Nunes, K.O.; Santos, A.C.; Bando, S.Y.; Silva, R.M.; Gomes, T.A.; Elias, W.P. Enteroaggregative Escherichia coli with uropathogenic characteristics are present in feces of diarrheic and healthy children. Pathog. Dis. 2017, 75, ftx106. [CrossRef]

101. Rossi, E.; Cimdins, A.; Lüthje, P.; Brauner, A.; Sjöling, Å.; Landini, P.; Römling, U. "It'sa gut feeling”—Escherichia coli biofilm formation in the gastrointestinal tract environment. Crit. Rev. Microbiol. 2018, 44, 1-30. [CrossRef]

102. Hebbelstrup Jensen, B.; Adler Sørensen, C.; Hebbelstrup Rye Rasmussen, S.; Rejkjær Holm, D.; Friis-Møller, A.; Engberg, J.; Mirsepasi-Lauridsen, H.C.; Struve, C.; Hammerum, A.M.; Porsbo, L.J. Characterization of diarrheagenic enteroaggregative Escherichia coli in danish adults—antibiotic treatment does not reduce duration of diarrhea. Front. Cell. Infect. Microbiol. 2018, 8, 306. [CrossRef]

103. Paletta, A.C.; Castro, V.S.; Conte-Junior, C.A. Shiga toxin-producing and enteroaggregative Escherichia coli in animal, foods, and humans: Pathogenicity mechanisms, detection methods, and epidemiology. Curr. Microbiol. 2020, 77, 612-620. [CrossRef]

104. Ellis, S.J.; Yasir, M.; Browning, D.F.; Busby, S.J.; Schüller, S. Oxygen and contact with human intestinal epithelium independently stimulate virulence gene expression in enteroaggregative Escherichia coli. Cell. Microbiol. 2019, 21, e13012. [CrossRef] [PubMed]

105. Vieira, P.C.; Espinoza-Culupú, A.O.; Nepomuceno, R.; Alves, M.R.; Lebrun, I.; Elias, W.P.; Ruiz, R.C. Secreted autotransporter toxin (Sat) induces cell damage during enteroaggregative Escherichia coli infection. PLoS ONE 2020, 15, e0228959. [CrossRef]

106. Le Bouguénec, C.; Servin, A.L. Diffusely adherent Escherichia coli strains expressing Afa/Dr adhesins (Afa/Dr DAEC): Hitherto unrecognized pathogens. FEMS Microbiol. Lett. 2006, 256, 185-194. [CrossRef] [PubMed]

107. Mansan-Almeida, R.; Pereira, A.L.; Giugliano, L.G. Diffusely adherent Escherichia coli strains isolated from children and adults constitute two different populations. BMC Microbiol. 2013, 13, 1-14. [CrossRef]

108. Singh, T.; Das, S.; Ramachandran, V.; Dar, S.A.; Snehaa, K.; Saha, R.; Shah, D. Spectrum of diarrhoeagenic Escherichia coli in paediatric population suffering from diarrhoea and as commensals in healthy children. Indian J. Med. Microbiol. 2017, 35, 204-210. [CrossRef] [PubMed]

109. Cabrera-Sosa, L.; Ochoa, T.J. Escherichia coli diarrhea. In Hunter's Tropical Medicine and Emerging Infectious Diseases; Elsevier: Amsterdam, The Netherlands, 2020; pp. 481-485.

110. Walczuk, U.; Sobieszczańska, B.; Turniak, M.; Rzeszutko, M.; Duda-Madej, A.; Iwańczak, B. The prevalence of mucosa-associated diffusely adherent Escherichia coli in children with inflammatory bowel disease. Adv. Clin. Exp. Med. 2019, $28,899-905$.

111. Chellapandi, K.; Ralte, L.; De Mandal, S.; Kumar, N.S.; Dutta, T.K.; Sharma, I. Diffusely Adherent E. coli Burden in Low Socio-Economic Pediatric Population. J. Med. Bacteriol. 2019, 8, 44-55.

112. Javadi, K.; Mohebi, S.; Motamedifar, M.; Hadi, N. Characterization and antibiotic resistance pattern of diffusely adherent Escherichia coli (DAEC), isolated from paediatric diarrhoea in Shiraz, southern Iran. New Microbes New Infect. 2020, $38,100780$. [CrossRef] 
113. Ageorges, V.; Monteiro, R.; Leroy, S.; Burgess, C.M.; Pizza, M.; Chaucheyras-Durand, F.; Desvaux, M. Molecular determinants of surface colonisation in diarrhoeagenic Escherichia coli (DEC): From bacterial adhesion to biofilm formation. FEMS Microbiol. Rev. 2020, 44, 314-350. [CrossRef]

114. Barrios-Villa, E.; de la Peña, C.F.M.; Lozano-Zaraín, P.; Cevallos, M.A.; Torres, C.; Torres, A.G.; del Carmen Rocha-Gracia, R. Comparative genomics of a subset of adherent/invasive Escherichia coli strains isolated from individuals without inflammatory bowel disease. Genomics 2020, 112, 1813-1820. [CrossRef] [PubMed]

115. Meza-Segura, M.; Estrada-Garcia, T. Diffusely adherent Escherichia coli. In Escherichia coli in the Americas; Springer: Berlin/Heidelberg, Germany, 2016; pp. 125-147.

116. Garrine, M.; Matambisso, G.; Nobela, N.; Vubil, D.; Massora, S.; Acácio, S.; Nhampossa, T.; Alonso, P.; Mandomando, I. Low frequency of enterohemorrhagic, enteroinvasive and diffusely adherent Escherichia coli in children under 5 years in rural Mozambique: A case-control study. BMC Infect. Dis. 2020, 20, 1-6. [CrossRef]

117. Martinez-Medina, M. Pathogenic Escherichia coli: Infections and Therapies; MDPI: Basel, Switzerland, 2021.

118. Palmela, C.; Chevarin, C.; Xu, Z.; Torres, J.; Sevrin, G.; Hirten, R.; Barnich, N.; Ng, S.C.; Colombel, J.-F. Adherent-invasive Escherichia coli in inflammatory bowel disease. Gut 2018, 67, 574-587. [CrossRef] [PubMed]

119. Shaler, C.R.; Elhenawy, W.; Coombes, B.K. The unique lifestyle of Crohn's disease-associated adherent-invasive Escherichia coli. J. Mol. Biol. 2019, 431, 2970-2981. [CrossRef]

120. Graham, D.B.; Xavier, R.J. Pathway paradigms revealed from the genetics of inflammatory bowel disease. Nature 2020, 578, 527-539. [CrossRef] [PubMed]

121. Caruso, R.; Lo, B.C.; Núñez, G. Host-microbiota interactions in inflammatory bowel disease. Nat. Rev. Immunol. 2020, 20, 411-426. [CrossRef] [PubMed]

122. Liu, S.; Zhao, W.; Lan, P.; Mou, X. The microbiome in inflammatory bowel diseases: From pathogenesis to therapy. Protein Cell 2020, 12, 331-345. [CrossRef]

123. Chervy, M.; Barnich, N.; Denizot, J. Adherent-Invasive E. coli: Update on the Lifestyle of a Troublemaker in Crohn's Disease. Int. J. Mol. Sci. 2020, 21, 3734. [CrossRef]

124. Lee, J.G.; Han, D.S.; Jo, S.V.; Lee, A.R.; Park, C.H.; Eun, C.S.; Lee, Y. Characteristics and pathogenic role of adherent-invasive Escherichia coli in inflammatory bowel disease: Potential impact on clinical outcomes. PLoS ONE 2019, 14, e0216165.

125. Mazzarella, G.; Perna, A.; Marano, A.; Lucariello, A.; Rotondi Aufiero, V.; Sorrentino, A.; Melina, R.; Guerra, G.; Taccone, F.S.; Iaquinto, G. Pathogenic role of associated adherent-invasive Escherichia coli in Crohn's disease. J. Cell. Physiol. 2017, 232, 2860-2868. [CrossRef] [PubMed]

126. Shawki, A.; McCole, D.F. Mechanisms of intestinal epithelial barrier dysfunction by adherent-invasive Escherichia coli. Cell. Mol. Gastroenterol. Hepatol. 2017, 3, 41-50. [CrossRef]

127. Perna, A.; Hay, E.; Contieri, M.; De Luca, A.; Guerra, G.; Lucariello, A. Adherent-invasive Escherichia coli (AIEC): Cause or consequence of inflammation, dysbiosis, and rupture of cellular joints in patients with IBD? J. Cell. Physiol. 2020, 235, 5041-5049. [CrossRef] [PubMed]

128. Yang, Y.; Liao, Y.; Ma, Y.; Gong, W.; Zhu, G. The role of major virulence factors of AIEC involved in inflammatory bowl disease-A mini-review. Appl. Microbiol. Biotechnol. 2017, 101, 7781-7787. [CrossRef] [PubMed]

129. Cogger-Ward, R. Characterisation of Putative Virulence Factors in Adherent-Invasive Escherichia coli. Ph.D. Thesis, University of Nottingham, Nottingham, UK, 2020.

130. Abdelhalim, K.A.; Uzel, A.; Ünal, N.G. Virulence determinants and genetic diversity of adherent-invasive Escherichia coli (AIEC) strains isolated from patients with Crohn's disease. Microb. Pathog. 2020, 145, 104233. [CrossRef] [PubMed]

131. Astley, D.; Masters, N.; Kuballa, A.; Katouli, M. Commonality of adherent-invasive Escherichia coli isolated from patients with extraintestinal infections, healthy individuals and the environment. Eur. J. Clin. Microbiol. Infect. Dis. 2021, 40, 181-192. [CrossRef] [PubMed]

132. Beata, S.; Michał, T.; Mateusz, O.; Urszula, W.; Choroszy, M.; Andrzej, T.; Piotr, D. Norepinephrine affects the interaction of adherent-invasive Escherichia coli with intestinal epithelial cells. Virulence 2021, 12, 630-637. [CrossRef]

133. Singh, P.; Metgud, S.C.; Roy, S.; Purwar, S. Evolution of diarrheagenic Escherichia coli pathotypes in India. J. Lab. Phys. 2019, 11, 346. [CrossRef]

134. Bogaerts, B.; Nouws, S.; Verhaegen, B.; Denayer, S.; Van Braekel, J.; Winand, R.; Fu, Q.; Crombé, F.; Piérard, D.; Marchal, K. Validation strategy of a bioinformatics whole genome sequencing workflow for Shiga toxin-producing Escherichia coli using a reference collection extensively characterized with conventional methods. Microb. Genom. 2021, 7, 000531.

135. Deurenberg, R.H.; Bathoorn, E.; Chlebowicz, M.A.; Couto, N.; Ferdous, M.; García-Cobos, S.; Kooistra-Smid, A.M.; Raangs, E.C.; Rosema, S.; Veloo, A.C. Application of next generation sequencing in clinical microbiology and infection prevention. J. Biotechnol. 2017, 243, 16-24. [CrossRef] [PubMed] 